\title{
Prevalence of hepatitis B and C infections and associated factors among blood donors in Aden city, Yemen
}

A.A. Al-Waleedi ${ }^{1}$ and Y.S. Khader ${ }^{2}$

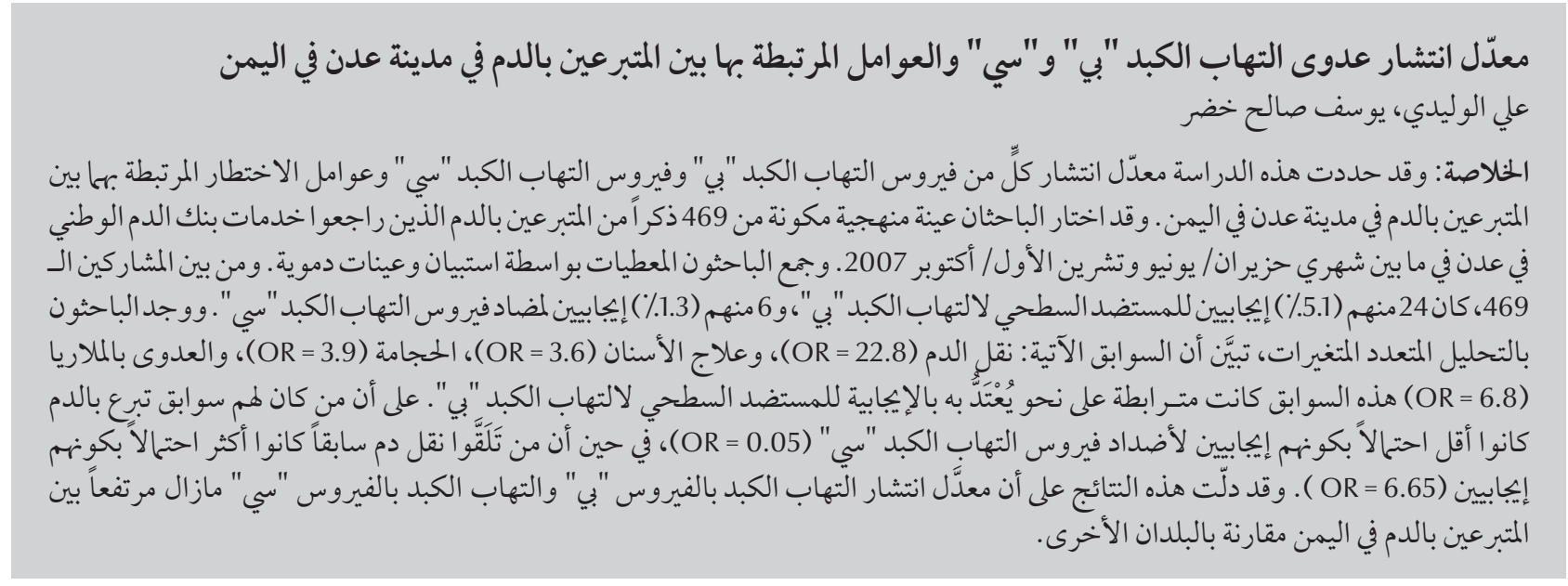

ABSTRACT This study determined the prevalence of hepatitis B virus (HBV) and hepatitis C virus (HCV) and associated risk factors among blood donors in Aden city, Yemen. A systematic sample of 469 male blood donors was selected from those attending the national blood bank service in Aden between June and October 2007. Data were collected by questionnaire and blood samples collected. Of the 469 participants, 24 (5.1\%) were positive for HBsAg and 6 (1.3\%) for anti-HCV. In multivariate analysis, history of: blood transfusion (OR = 22.8), dental treatment $(O R=3.6)$, cupping $(O R=3.9)$ and malaria infection $(O R=6.8)$ were significantly associated with being positive for HBsAg. Those with history of blood donation were less likely to be positive for $\mathrm{HBs} A g(\mathrm{OR}=$ 0.17). Those with a history of blood donation were significantly less likely to be positive for anti-HCV positivity (OR $=0.05)$, while those with history of blood transfusion were more likely to test positive $(\mathrm{OR}=65.6)$. The prevalence of HBV and HCV among blood donors in Yemen is still high compared to many other countries.

Prévalence des infections par les virus de l'hépatite $B$ et $C$ et facteurs associés chez des donneurs de sang dans la ville d'Aden (Yémen)

RÉSUMÉ La présente étude a déterminé la prévalence des infections à hépatite $B$ et $C$ et les facteurs de risque associés chez des donneurs de sang dans la ville d'Aden (Yémen). Un échantillon systématique de 469 donneurs de sang de sexe masculin a été sélectionné à partir de donneurs fréquentant le service national de la banque de sang dans la ville d'Aden entre juin et octobre 2007. Des données ont été recueillies par questionnaire et des échantillons de sang ont été prélevés. Parmi les 469 participants, 24 étaient positifs pour les antigènes de surface du virus de l'hépatite B (5,1\%) et 6 pour les anticorps contre le virus de l'hépatite C (1,3\%). Dans une analyse multivariée, les antécédents de transfusion sanguine (O.R. = 22,8), de traitement dentaire (O.R. =3,6), d'application de ventouses $(O . R .=3,9)$ et de paludisme $(O . R .=6,8)$ étaient fortement associés à la positivité aux antigènes de surface du virus de l'hépatite B. Les personnes ayant déjà fait don de leur sang avaient moins de risque d'être positives pour les antigènes de surface du virus de l'hépatite B $(O . R .=0,17)$. Ces dernières avaient aussi beaucoup moins de risque d'être positives pour les anticorps contre le virus de l'hépatite C (O.R. = 0,05), contrairement aux personnes ayant reçu des transfusions sanguines (O.R. = 65,6). Par rapport à de nombreux autres pays, la prévalence de l'infection par les virus de l'hépatite $\mathrm{B}$ et $\mathrm{C}$ chez les donneurs de sang reste élevée au Yémen

${ }^{\top}$ Department of Community Medicine, Public Health and Family Medicine, Faculty of Medicine, Aden University, Yemen

${ }^{2}$ Department of Community Medicine, Public Health and Family Medicine, Faculty of Medicine, Jordan University of Science \& Technology, Irbid, Jordan (Correspondence to Y.S. Khader: yousef.k@excite.com).

Received: 24/07/11; accepted: 12/12/11 


\section{Introduction}

Infection with hepatitis B virus (HBV) and hepatitis $\mathrm{C}$ virus (HCV) causes considerable morbidity and mortality worldwide $[1,2]$. In Yemen, chronic hepatitis is an important cause of cirrhosis and liver cancer but studies on the prevalence of these viruses in the general population are scarce [3]. Among Middle Eastern countries, Bahrain, Islamic Republic of Iran and Kuwait have low HBV endemicity; Cyprus, Iraq and United Arab Emirates have intermediate endemicity; while Egypt, Jordan, Oman, Palestine, Yemen and Saudi Arabia have high endemicity [4]. In 1988 a seroepidemiological survey of hepatitis A, $B$ and $D$ was performed in the Yemen [5]. The prevalence of hepatitis B surface antigen (HBsAg) was $12.7 \%$. Using multivariate analysis, age, past history of jaundice, and combined history of blood transfusion and surgery were independent predictors of hepatitis B infection [5].

The prevalence rates of HBsAg among volunteer blood donors in developing countries are much higher than that reported in developed countries [6]. This reflects the efficacy of blood donor selection policies, effective screening and very low HBV prevalence in the general population in these countries. Volunteer blood donors are generally regarded as a healthier segment of any community, as blood banks usually have strict selection criteria. [7]. The proportion of donors with hepatitis and the risk factors associated with the disease among these healthy individuals may reflect the magnitude of chronic $\mathrm{HBV}$ and $\mathrm{HCV}$ infection in the general population.

The awareness of the importance of blood safety for controlling the transmission of HBV and HCV has helped to decrease the spread of these viruses. Public health interventions and strategies have been shown to be effective method of preventing such infection. Any strategy to prevent these infections must therefore be based on accurate data, including information about prevalence and risk factors of these infections. Therefore, this study was conducted to determine the prevalence of HBV and HCV and their associated factors among blood donors at Aden city, Yemen. Such information may raise awareness regarding the need for urgent action to prevent $\mathrm{HBV}$ and $\mathrm{HCV}$ transmission in Yemen.

\section{Methods}

\section{Study population}

This study was conducted among all blood donors who attended the national blood bank service in Aden in Yemen between June and October 2007. Blood donation operates on an exchange basis in which relatives and friends of patients are requested to donate blood for their clinical management. A systematic sample was obtained by selecting all blood donors attending the national blood bank every other day. For cultural reasons, only males who consider themselves healthy donate blood. The staff at the national blood bank informed donors about their infectious status and those who were found to be infected were counselled and referred to seek medical attention.

\section{Data collection}

A structured self-administered questionnaire was used to collect data. The questionnaire was filled through face-to-face interview by a trained public health specialist (first author) for those who could not read and write. The questionnaire sought information about personal characteristics such as age, gender, level of education, marital status, number of wives, number of children, residency, occupational history, previous blood donation, and history of: blood transfusion, haemodialysis, cupping, travel outside the country, malaria, hepatitis B vaccination, surgical procedures and dental treatment. History of malaria infection was determined by asking the participants whether they had ever had physiciandiagnosed malaria.

\section{Laboratory testing}

Blood samples were routinely collected from blood donors at the national blood bank. Testing of specimens was performed at the laboratories of virology unit of the national blood bank. Blood was screened for HBsAg using a hepatitis $\mathrm{B}$ antigen detection kit/enzyme immunoassay (PRC, Germany). Hepatitis $C$ infection was measured with IMx HCV version 3.0 (Abott, Germany). Manufacturer's instructions were followed.

\section{Ethical considerations}

Written consent was obtained from the respondents who agreed to participate in this study. The respondents were assured about the confidentiality of the information and that the laboratory results would not be disclosed to any other persons.

\section{Statistical analysis}

Data are presented as frequency distributions for categorical variables. Differences in the prevalence of hepatitis between patients according to the variables examined were tested with the Pearson chi-squared test. Multivariate analysis using binary logistic regression was used to identify factors associated with HBsAg and anti-HCV. Data were analysed using SPSS, version 11.5. A $P$-value of less than 0.05 was considered statistically significant.

\section{Results}

\section{Participant's characteristics}

A total of 495 male blood donors who attended the national blood bank service of Yemen (Aden) between June and October, 2007 were approached 
and invited to participate in this study. Of those, 469 (94.7\%) agreed to participate in this study. Of the 469 participants, 27 (5.8\%) were interviewed face to face because there were illiterate. The age of participants ranged between 18 and 59 years with a mean of 29.3 years. Their sociodemographic, clinical, and relevant characteristics are shown in Table 1. More than half of the participants (56.3\%) had less than high school education. About $76 \%$ were living in Aden and 24.1\% were living in other governorates. About two-thirds (64\%) were donating blood for the first time.

\section{Prevalence of HBV and HCV}

Of the 469 Yemeni blood donors, 24 (5.1\%) were positive for HBsAg and 6 (1.3\%) where positive for anti-HCV. The prevalence of positive HBsAg and positive anti-HCV according to sociodemographic and relevant characteristics is shown in Table 2. There was no difference in the prevalence of hepatitis $\mathrm{B}$ and hepatitis $\mathrm{C}$ in donors according to their sociodemographic status. The prevalence of hepatitis $\mathrm{B}$ and hepatitis $C$ was significantly lower among those with history of blood donations $(P=$ $0.01)$ and higher among those with a history of blood transfusion $(P=0.01)$, dental treatment $(P=0.01)$, cupping $(P=0.04)$ and malaria infection $(P=$ $0.04)$.

\section{Multivariate analysis}

In the multivariate analysis (Table 3), after adjustment for all other variables, history of blood transfusion $(\mathrm{OR}=$ 22.8), dental treatment $(\mathrm{OR}=3.6)$, cupping $(\mathrm{OR}=3.9)$ and malaria infection $(\mathrm{OR}=6.8)$ remained significantly associated with increased odds of being positive for HBsAg. Those with history of blood donation were significantly less likely to be positive for HBsAg.

The odds of having positive anti$\mathrm{HCV}$ differed significantly between participants according to the history of blood donation and history of blood transfusion. Frequent blood donors were less likely to test positive for AntiHCV whereas those with history of blood transfusion were more likely to test positive for anti-HCV.

\section{Discussion}

The prevalence of hepatitis B among blood donors at the national blood bank service in Aden Governorate, Yemen found in this study was 5.1\%. Much higher rates $(7.1 \%, 9.8 \%, 15 \%$ and $6.7 \%$ ) have previously been reported among Yemeni blood donors [8-10]. These differences in the prevalence rates might be explained by the geographical differences in the availability of services and programmes or might reflect a true reduction in prevalence over time. The prevalence of HBsAg in the general population seems to be relatively high in Yemen. In a seroepidemiological survey of hepatitis in Yemen in 1988, Scott et al. reported a prevalence of HBsAg of $12.7 \%$ [5]. Although it is difficult to compare the prevalence rates reported in our study (among blood donors) with that reported by Scott et al. (among the general population), it seems that the rate of HBsAg has decreased dramatically. Introducing hepatitis $B$ vaccine within the national immunization programmes, improvement of the people's knowledge about hepatitis risk factors through educational programmes, and the availability of measures to diagnose hepatitis in health centres and blood banks might

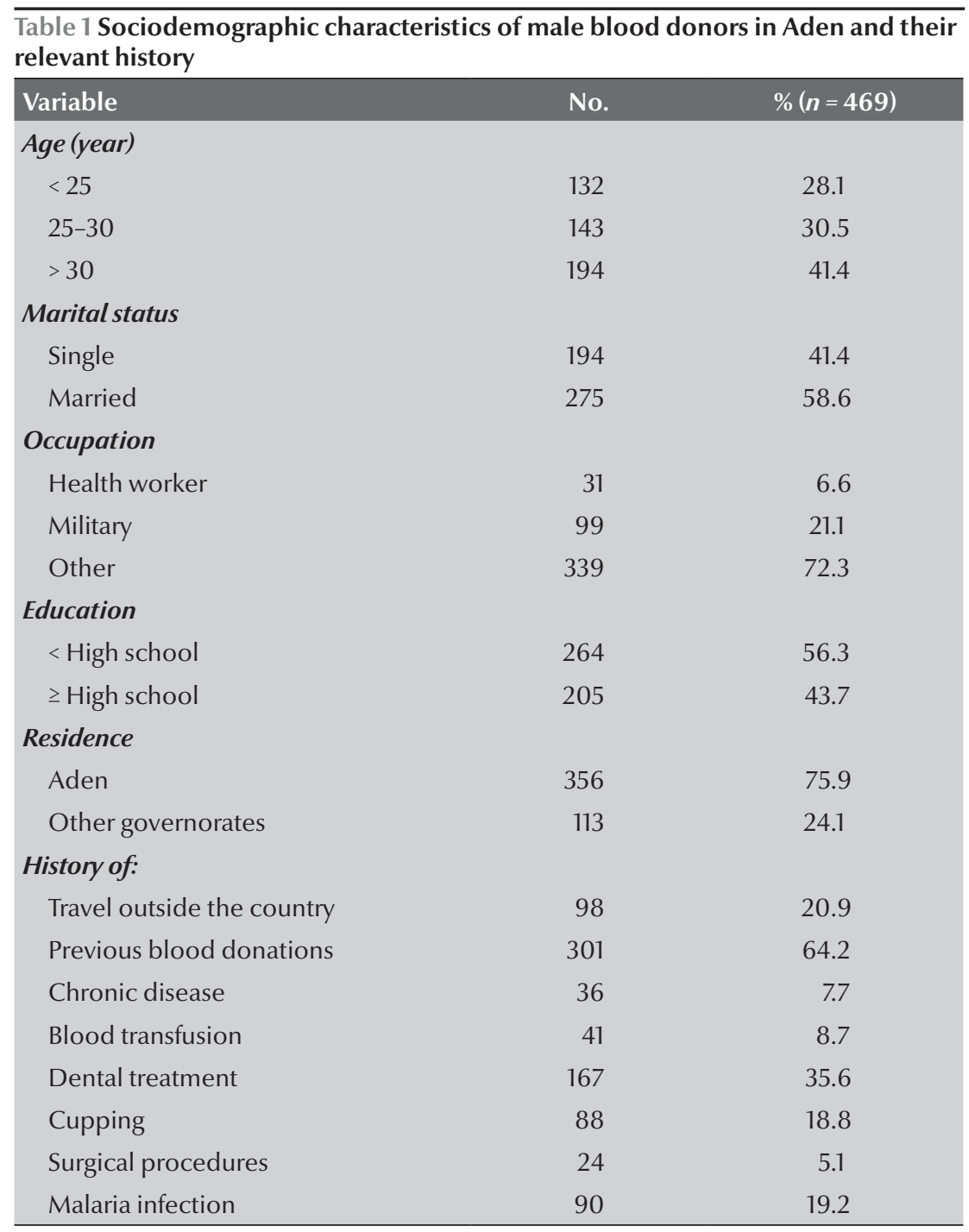




\begin{tabular}{|c|c|c|c|c|c|c|}
\hline \multirow[t]{3}{*}{ Variable } & \multicolumn{2}{|c|}{ Hepatitis B } & \multirow[t]{3}{*}{$P$-value } & \multicolumn{2}{|c|}{ Hepatitis C } & \multirow[t]{3}{*}{$P$-value } \\
\hline & No & Yes & & No & Yes & \\
\hline & No. (\%) & No. (\%) & & No. (\%) & No. (\%) & \\
\hline Age group (years) & & & 0.42 & & & 0.80 \\
\hline$<25$ & 127 (96.9) & $4(3.1)$ & & $127(99.2)$ & $1(0.8)$ & \\
\hline $25-30$ & $133(94.3)$ & $8(5.7)$ & & 133 (98.5) & $2(1.5)$ & \\
\hline$\geq 30$ & 179 (93.7) & $12(6.3)$ & & $179(98.4)$ & $3(1.6)$ & \\
\hline Marital status & & & 0.68 & & & 0.68 \\
\hline Single & 183 (95.3) & $9(4.7)$ & & 183 (98.9) & $2(1.1)$ & \\
\hline Married & $256(94.5)$ & $15(5.5)$ & & $256(98.5)$ & $4(1.5)$ & \\
\hline Occupation & & & 0.41 & & & 0.77 \\
\hline Health worker & $28(90.3)$ & $3(9.7)$ & & $28(100.0)$ & $0(0.0)$ & \\
\hline Military & $92(93.9)$ & $6(6.1)$ & & $92(98.9)$ & $1(1.1)$ & \\
\hline Other & 319 (95.5) & $15(4.5)$ & & 319 (98.5) & $5(1.5)$ & \\
\hline Education & & & 0.53 & & & 0.77 \\
\hline$<$ High school & $246(94.3)$ & $15(5.7)$ & & $246(98.8)$ & $3(1.2)$ & \\
\hline$\geq$ High school & $193(95.5)$ & $9(4.5)$ & & 193 (98.5) & $3(1.5)$ & \\
\hline Residence & & & 0.27 & & & 0.57 \\
\hline Aden & $336(95.5)$ & $16(4.5)$ & & 336 (98.8) & $4(1.2)$ & \\
\hline Other & 103 (92.8) & $8(7.2)$ & & $103(98.1)$ & $2(1.9)$ & \\
\hline \multicolumn{7}{|l|}{ History of: } \\
\hline Previous blood donation & & & 0.02 & & & 0.01 \\
\hline No & $149(91.4)$ & $14(8.6)$ & & $149(96.8)$ & $5(3.2)$ & \\
\hline Yes & $290(96.7)$ & $10(3.3)$ & & $290(99.7)$ & $1(0.3)$ & \\
\hline Chronic disease & & & 0.35 & & & 0.38 \\
\hline No & $407(95.1)$ & $21(4.9)$ & & 407 (98.8) & $5(1.2)$ & \\
\hline Yes & $32(91.4)$ & $3(8.6)$ & & $32(97.0)$ & $1(3.0)$ & \\
\hline Blood transfusion & & & 0.01 & & & 0.01 \\
\hline No & $415(97.4)$ & $11(2.6)$ & & 415 (99.5) & $2(0.5)$ & \\
\hline Yes & $24(64.9)$ & $13(35.1)$ & & $24(85.7)$ & $4(14.3)$ & \\
\hline Dental treatment & & & 0.01 & & & 0.01 \\
\hline No & $294(97.7)$ & $7(2.3)$ & & $294(99.7)$ & $1(0.3)$ & \\
\hline Yes & $145(89.5)$ & $17(10.5)$ & & $145(96.7)$ & $5(3.3)$ & \\
\hline Cupping & & & 0.01 & & & 0.04 \\
\hline No & $364(96.3)$ & $14(3.7)$ & & $364(99.2)$ & $3(0.8)$ & \\
\hline Yes & $75(88.2)$ & $10(11.8)$ & & $75(96.2)$ & $3(3.8)$ & \\
\hline Surgical procedures & & & 0.82 & & & 0.56 \\
\hline No & $416(94.8)$ & $23(5.2)$ & & $416(98.6)$ & $6(1.4)$ & \\
\hline Yes & $23(95.8)$ & $1(4.2)$ & & $23(100.0)$ & $0(0.0)$ & \\
\hline Travel outside the country & & & 0.13 & & & 0.83 \\
\hline No & $350(95.6)$ & $16(4.4)$ & & $350(98.6)$ & $5(1.4)$ & \\
\hline Yes & 89 (91.8) & $8(8.2)$ & & $89(98.9)$ & $1(1.1)$ & \\
\hline Malaria infection & & & 0.01 & & & 0.04 \\
\hline No & $363(96.5)$ & $13(3.5)$ & & $363(99.2)$ & $3(0.8)$ & \\
\hline Yes & $76(87.4)$ & $11(12.6)$ & & $76(96.2)$ & $3(3.8)$ & \\
\hline
\end{tabular}




\begin{tabular}{|c|c|c|c|c|}
\hline \multirow[t]{2}{*}{ Variable } & \multicolumn{2}{|c|}{ Hepatitis B } & \multicolumn{2}{|c|}{ Hepatitis C } \\
\hline & OR $(95 \% \mathrm{CI})$ & $P$-value & OR $(95 \% \mathrm{CI})$ & $P$-value \\
\hline \multicolumn{5}{|l|}{ History of: } \\
\hline Blood donation & $0.17(0.06-0.50)$ & 0.01 & $0.05(0.005-0.517)$ & 0.01 \\
\hline Blood transfusion & $22.80(7.20-72.30)$ & 0.01 & $65.60(9.40-459.80)$ & 0.01 \\
\hline Dental treatment & $3.60(1.20-10.40)$ & 0.02 & & \\
\hline Cupping & $3.90(1.30-11.30)$ & 0.01 & & \\
\hline Malaria infection & $6.80(2.30-20.50)$ & 0.01 & & \\
\hline
\end{tabular}

$O R=$ odds ratio $; C I=$ confidence interval .

explain this decrease. Many other studies in nearby countries have shown a lower prevalence of hepatitis B among blood donors, including Saudi Arabia (4.0\%) [11], Egypt (4.3\%) [12] and Pakistan (3.3\%) [13]. This may be because there was insufficient protection for patients admitted to hospitals in Yemen. Sterilization, disinfection and general standards of training and proficiency are generally lacking in most hospitals in Yemen.

Our study demonstrated that no previous blood donation, history of blood transfusion, history of dental procedures, history of cupping and previous infection with malaria were associated with increased odds of hepatitis B infection. The significant association between HBsAg positivity and history of blood transfusion, cupping and dental treatment is consistent with the findings of other studies $[14,15]$. The association between previous infection with malaria and $\mathrm{HBsAg}$ positivity $(\mathrm{OR}=6.8)$ may relate to impaired clearance of liver parasites in the presence of the reduced level of HLA class I antigen expression on hepatocytes infected by HBV [16]. In a case-controlstudy in Gambia, the prevalence of HBV was significantly increased amongst children with severe Plasmodium falciparum malaria compared to matched controls [16]. Barcus et al. found a prevalence of $\mathrm{HBV}$ infection of $24 \%$ in adult Vietnamese patients admitted with severe P. falciparum malaria, which was higher than the estimated $10 \%$ prevalence of $\mathrm{HBV}$ in that area [17].Previous studies have shown that the prevalence rates of malaria in Yemen ranged between 12.8\% and $18.6 \%$ [18-20] and males are more infected [20]. The association between HBV positivity and malaria may relate to impaired clearance of the liver-stage malaria parasites, as a result of HBV infection of the hepatocytes. Also, protein levels in the body may reflect the immunity status of an individual; hence, any adverse influence may increase the vulnerability to hepatitis B infection.

We found that $1.3 \%$ of the blood donors were positive for anti-HCV. A similar study among blood donors in Yemen reported that about $1.1 \%$ of the donors in Hajja Governorate were infected with hepatitis C [10]. Sallam et al. reported a prevalence of hepatitis C in 2003 of $0.2 \%$ in Sana'a and $0.6 \%$ in Aden [9]. The prevalence of hepatitis $\mathrm{C}$ among blood donors is higher than that reported from the neighbouring countries including Oman $(0.5 \%)$ and Saudi Arabia (1.0\% ) [21,22]. Such small differences in prevalence rates may be explained by methodological differences between studies.

Only history of blood donation and blood transfusion were significantly associated with HCV infection in our study. First-time blood donors were 20 times more likely to have HCV infection compared with frequent donors. This association is plausible since first-time blood donors have never been screened. The lack of an associations between HCV infection and other variables, including malaria, may be explained by the fact that only 6 people were positive for anti-HCV.

The seroprevalence rates of hepatitis $B$ and hepatitis $C$ are high in Yemen and nationwide efforts are required to identify infected individuals. Transmission of hepatitis B and C through unscreened blood transfusion, reuse of unsterilized syringes and medical equipment is well documented in the pertinent literature. Moreover, people having cupping, history of dental treatment, circumcision and shaving by barbers are also at increased risk due to reuse of equipment. Efforts should be made for the promotion of behaviour changes among the public and health care workers to use sterilized medical instruments and screened blood.

In conclusion, the prevalence of hepatitis $\mathrm{B}$ and $\mathrm{C}$ among blood donors in Yemen is still high compared to many other countries. Given the lack of information on the prevalence of hepatitis B and C in the general population in Yemen, we recommend a population-based study for the assessment of hepatitis $\mathrm{B}$ and $\mathrm{C}$ prevalence as a first step to implement control measures. Increased coverage of hepatitis B vaccination would further reduce that rate. 


\section{References}

1. Mathers CD, Loncar D. Projections of global mortality and burden of disease from 2002 to 2030. PLoS Medicine, 2006, 3:e512.

2. Perz JF et al. The contributions of hepatitis B virus and hepatitis $C$ virus infections to cirrhosis and primary liver cancer worldwide. Journal of Hepatology, 2006, 45:529-538.

3. Jadallah $\mathrm{R}$ et al. Prevalence of hepatitis B virus markers among high risk groups in Palestine. Medical Journal of Islamic World Academy of Sciences, 2005,15:4:157-160.

4. Andre F. Hepatitis B epidemiology in Asia, the Middle East and Africa. Vaccine, 2000, 18:20-22.

5. Scott DA et al. A seroepidemiological survey of viral hepatitis in Yemen Arab Republic. Transactions of the Royal Society of Tropical Medicine and Hygiene, 1990, 84(2):288-291.

6. Odusanya OO et al. Prevalence of hepatitis B surface antigen in vaccinated children and controls in rural Nigeria. International Journal of Infectious Diseases, 2005, 9(3):139-143.

7. Pillonel J, Saura C, Couroucé AM. Prévalence du VIH, de l'HTt $L V$ et des virus des hépatites $B$ et $C$ chez les donneurs de sang en France, 1992-1996 [Prevalence of HIV, HTLV, and hepatitis $B$ and C viruses in blood donors in France, 1992-1996]. Transfusion Clinique et Biologique, 1998, 5:305-312.

8. Al-Nassiri KA, Raja'a YA. Hepatitis B infection in Yemenis in Sana'a: pattern and risk factors. Eastern Mediterranean Health Journal, 2001,7(1-2):147-152.

9. Sallam TA et al. Prevalence of blood-borne viral hepatitis in different community in Yemen. Epidemiology and Infection, 2003, 131(1):771-775.

10. Haidar NA. Prevalence of hepatitis B and hepatitis C in blood donors and high risk groups in Hajjah, Yemen Republic. Saudi Medical Journal, 2002, 23(9):1090-1094.

11. Altamimi W et al. Prevalence of HBsAg and Anti-HCV in Saudi blood donors. Annals of Saudi Medicine, 1998,18(1):60-62.
12. El-Gilany AH, El-Fedawy S. Bloodborne infections among student voluntary blood donors in Mansoura University, Egypt. African Health Sciences, 2005, 5(1):55-58

13. Khattak MF et al. Seroprevalence of hepatitis B, C and HIV in blood donors in northern Pakistan. Journal of the Pakistan Medical Association, 2002, 52(9):398-402.

14. Alizadeh AH et al. Seroprevalence of hepatitis B in Nahavand, Islamic Republic of Iran. Eastern Mediterranean Health Journal, 2006, 12(5):528-537.

15. Vahid T et al. Hepatitis B prevalence and risk factors in blood donors in Ghazvin, I.R. Iran. Hepatitis Monthly, 2005, 5:117-122.

16. Thursz MR et al. Association of hepatitis B surface antigen carriage with severe malaria in Gambian children. Nature Medicine, 1995,1(4):374-375.

17. Barcus MJ et al. Short report: hepatitis B infection and severe Plasmodium falciparum malaria in Vietnamese adults. American Journal of Tropical Medicine and Hygiene, 2002, 66(2):140-142.

18. Alkadi HO, Al-Maktari MT, Nooman MA. Chloroquine-resistant Plasmodium falciparum local strain in Taiz Governorate, Republic of Yemen. Chemotherapy, 2006, 52:166-170.

19. Al-Maktari MT et al. Malaria status in Al-Hodeidah Governorate, Yemen: malariometric parasitic survey and chloroquine resistance $P$. falciparum local strain. Journal of the Egyptian Society of Parasitology, 2003, 33:361-372.

20. Al-Taiar A et al. Severe malaria in children in Yemen: two-site observational study. British Medical Journal, 2006, 333:827.

21. Al Dhahry $\mathrm{S}$ et al. Laboratory diagnosis of viral hepatitis $\mathrm{C}$. The Sultan Qaboos University Hospital Experience. Sultan Qaboos University Medical Journal, 2003, 5:15-20.

22. Altamimi W et al. Prevalence of HBsAg and Anti -HCV in Saudi blood donors. Annals of Saudi Medicine, 1998, 18(1):60-62. 